\title{
Market Structure, Macroeconomic Shocks, and Banking Risk in Kenya
}

\author{
Nderitu Kingori* \\ *School of Economics, University of Nairobi \\ Submitted: June 21, 2016 • Accepted: September 7, 2016
}

\begin{abstract}
This paper investigates the effect of changing market structure and macroeconomic shocks on the borrowing and lending risk exposure of Kenyan commercial banks using a GMM estimation approach. Borrowing risk exposure was found not to be persistent, being mainly affected by the degree of concentration and external economic shocks. Interestingly, the results also suggest that changes in the short-term interest rate do not affect the net interest margin, which may imply that bank deposit and lending rates are rigid and that the interest rate channel may be ineffective. The lending risk exposure was found to be persistent, and it was affected by the degree of concentration, internal economic shocks, and external economic shocks. The positive relationship between degree of concentration as well as borrowing and lending risk exposure supports the concentration-fragility view, as the declining franchise value did not lower incentives for making good loans during the study period where the degree of concentration was on a downward trend. Further analysis of the factors contributing to the persistence of lending risk exposure using a PVAR model found that the banks' loan growth rate and the market interest rate were key determinants. The effect of the loan growth rate was about double the effect of interest rate risk, implying that risk taking by some of the medium-sized and small banks is the key determinant of the persistence of lending risk exposure.
\end{abstract}

JEL classification: C23, E02, G21, G31

Keywords: market structure, macroeconomic shocks, macro-financial linkages, banking risk, dynamic panel data, Kenyan banks

*Corresponding Author. Email: nderitukb@gmail.com 


\section{Introduction}

Banks are generally in the business of managing financial risk, because they earn their profits mainly by taking on specific forms of risk. Heffernan (2005) explained that risk management is a bank's core business. Banks face a number of financial risks that are atypical to those faced by non-financial firms and inadequate management of these risks can threaten their profitability, solvency, and shareholder value-added.

The first phase of the financial liberalization process in Kenya began in 1989 resulting in the deregulation of various banking activities, the reduction of reserve requirements, and the implementation of various other policy measures aimed at increasing competition in the banking sector (Ngugi and Kabubo, 1998). According to Central Bank of Kenya (2003), the second phase of reforms began in 2003 and was based on the findings of two studies: the Banking Sector Reform Strategy and the IMF's Financial Sector Assessment Program. These studies covered the adequacy of prudential regulation and supervision, interest rate spreads, banking sector risks and vulnerabilities, banking competition and costs, and improving access to financial services.

In addition to managing normal banking risks and the risk-taking opportunities created by financial liberalization, banks operating in developing countries such as Kenya were also exposed to frequent macroeconomic shocks. Agenor and Montiel (2008) explained that these economic shocks arose mainly because most developing economies are characterized by unique internal and external factors that cause instability. Some of these internal factors included political instability, frequent changes in policy regimes, and weak institutions. External factors included trade volatility, exchange rates, and capital flows. However, Hausmann and Gavin (1996) found that though domestic and external economic shocks have contributed to macroeconomic volatility in developing countries, the economy's vulnerability to these changes has depended on its institutional structure and economic policy regimes. Similarly, Acemoglu et al. (2003) found that the main cause of macroeconomic volatility was not "bad" policies (such as excessive government spending, high inflation, and overvalued exchange rates), but rather the underlying institutional weaknesses. They explained that "weak institutions (such as political institutions that do not constrain politicians and political elites, have ineffective enforcement of property rights, widespread corruption, and a high degree of political instability) foster the adoption of distortionary macroeconomic policies, which in turn lead to macroeconomic volatility." In their study, Kilishi et al. (2013) found that with regard to the six governance indicators used to measure institutions, Kenya ranked poorly among Sub-Saharan Africa countries with respect to political stability, rule of law, and control of corruption.

Financial liberalization is therefore expected to influence banking risk exposure by affecting the ability and incentives for risk taking. Deregulation of the various banking activities 
increases the ability to take risks and the resulting competitive environment creates incentives to take additional risks to grow market share. Similarly, macroeconomic shocks are expected to influence banking risk exposure by affecting the economic performance of banks and their borrowers. Negative shocks reduce their earnings, which in turn affect bank capitalization. Positive shocks reduce risk perceptions, which creates an environment conducive to increased risk taking.

Various cross-country studies (Demirguc-Kunt and Detagiache, 1998; Bohachova, 2008; Allen et al., 2009; Laeven, 2011) that link macroeconomic shocks to banking risks have provided valuable insights on the specific macroeconomic shocks associated with banking vulnerabilities. Additionally, various other cross-country studies (Demirguc-Kunt and Detragiache, 2001; Weller, 2001; Goodhart et al., 2004; Agosin and Huaita, 2011) have also linked banking crises in developing economies to financial liberalization. The Kenyan financial system is predominantly bank-based; therefore, analyzing the effect of changes in market structure and macroeconomic shocks on the banking sector is important because of their potential to adversely affect the real economy by causing credit restrictions and costly liquidations that result in output losses and high unemployment.

According to Government of Kenya (2007), the financial services sector is expected to play a critical role in the mobilization of funds to implement Vision 2030 projects. ${ }^{1}$ However, this will be contingent on addressing some of the identified constraints such as the high interest rate spread, inadequate provisioning against losses from bad loans, and weak internal controls. One of the factors contributing to the high interest rate spread is the risk premium charged by banks to compensate for the uncertainty of macroeconomic variables and for the resulting effect of rising problem loans on bank capitalization. Therefore, a better understanding of the factors contributing to risk exposure may contribute to a reduction in the risk premium by improving bank risk management. This study may also generate policy implications by identifying the significant factors that affect banking risk. Finally, this research study will contribute to the empirical literature on the effect of financial liberalization and macroeconomic shocks on banking risk in Kenya.

The main objective of this study will be to analyze factors influencing the risk exposure of commercial banks in Kenya by focusing on two primary hypotheses. First, the changing market structure in the wake of financial liberalization increases banking fragility by increasing the ability and incentives for risk taking. Second, positive and negative macroeconomic shocks influence banking risk exposure by affecting the economic performance of banks and their borrowers.

The remainder of the paper is organized in four sections. Section 1 reviews some of

\footnotetext{
${ }^{1}$ Vision 2030 projects refers to development projects identified in the government's development plan as critical for the achievement of long-term development goals by the year 2030 .
} 
the relevant literature, section 2 explains the research methodology, section 3 reports the empirical results, and section 4 summarizes and concludes the paper.

\section{Literature Review}

\subsection{Market Structure and Banking Risk}

Degryse and Ongena (2005) explained that there are conflicting predictions about the relationship between bank rents and banking fragility in economic theory. According to the concentration-stability view there is a positive link between bank concentration and financial stability. The concentration-fragility view on the other hand, states that there is a positive link between bank concentration and financial fragility. Bank concentration affects financial stability because one of the key sources of bank rents is market structure, which consists of the number of banks in the market and the existence of alternative providers of finance.

The concentration-stability view is mainly based on the argument by Hellman et al. (2000), which stated that financial liberalization increases competition, and this resulting competition reduces profit margins. The lower profit margins result in lower franchise values (the value of expected future profits that act as intangible capital), and lower franchise values in turn lower incentives for making good loans. Therefore, the higher franchise values associated with concentration increase stability by lowering the incentives for risk-taking. The concentration-stability view is also based on the study by Allen and Gale (2004), who modeled how bank competition, as a result of financial liberalization, can induce banks to bid up deposit rates and reduce franchise value. Hellwig (1995) explained that the problem of "excessive risk taking" results from the disappearance of oligopoly rents due to the intensification of competition following deregulation, banks are tempted to replace oligopoly rents with premia on risk taking.

In contrast, the concentration-fragility view is based on the study by Boyd and De Nicolo (2005) who argued that the model used by Allen and Gale (2004) focused on banks' strategic interactions in deposit markets but ignored bank competition in loan markets. Instead, they claimed that market concentration could affect bank stability in different ways, depending on the net effect across the deposit and loan markets. Specifically, they pointed out that "concentration in the loan market can lead to increased lending rates that raise the borrowers' debt loads and default probabilities, as well as their incentive to engage in riskier projects."

A study by Mwega (2011) found that the Kenyan banking sector experienced reduced concentration during the period of 1998 to 2008, following the various financial reforms that were implemented. His analysis of bank peer groups found that small banks were the least competitive, followed by large banks and then medium-sized banks. However, the degree of 
competitiveness indicated that the Kenyan banking sector is still characterized by monopolistic competition, and this was also confirmed by the persistence-of-profit measure.

\subsection{Macroeconomic Factors and Banking Risk}

Bohachova (2008) pointed out that because banks perform intermediary functions for the real sector, they are exposed to the business cycle conditions that affect the real sector. Generally, the risks of intermediation rise as economic conditions worsen since banks become more vulnerable to adverse selection and moral hazard behaviour during periods of economic stagnation or recession. The main source of output fluctuations in developing countries, as explained by Agenor and Montiel (2008), is the supply shock that accounts for over half of the volatility in aggregate output, partly because a significant proportion of exports consist of a narrow range of primary commodities. In addition, shocks to the relative prices of imported goods and intermediate inputs also contribute to output volatility.

According to Stiglitz and Weiss (1981), high bank interest rates will affect the "riskiness" of a bank's loan portfolio by either discouraging safer potential borrowers (the adverse selection effect) or by inducing borrowers to invest in riskier projects (the incentive effect). DemirgucKunt and Detagiache (1998) argued that banks are also exposed to interest rate risk through their maturity transformation functions; therefore, a large increase in short-term interest rates is likely to be a major source of systemic banking problems. Greuning and Bratanovic (2003) explained that when interest rates change, a bank's earnings and expenses change along with the value of its assets, liabilities, and off-balance-sheet positions. Changing interest rates affect a bank's bond portfolio holdings by increasing the risk of reinvestment and the risk of realization (Esch et al., 2005), while high interest rates increase credit risk by contributing to firm failure (Nkurunziza, 2005) and increase liquidity risk by raising bank funding costs especially for small banks (Brownbridge, 1998).

Misati et al. (2013) pointed out that fuel and food inflation are the key drivers of inflation in Kenya, contributing to over $80 \%$ of overall inflation every month. This is because Kenya is a net importer of oil - changes in the international crude oil prices always affect the domestic inflation dynamics. Additionally, frequent food shortages following inadequate rainfall and occasional drought increase inflationary pressure that necessitates food importation. Increases in both oil and food prices depreciate the exchange rate immediately and have a more significant influence on non-food non-fuel inflation than the money supply growth rate. Bohachova (2008) found that high rates of inflation have a negative effect on the earnings of existing borrowers and therefore impair the quality of previously extended loans. Odhiambo (2012) found that the financial sector in developing countries becomes less developed as the inflation rate increases because inflation adversely affects the holding of all classes of financial assets. 
Greuning and Bratanovic (2003) explained that medium-sized and large banks in developing countries that maintain correspondent banking relationships with foreign banks or that support customer transactions denominated in foreign exchange are exposed to higher levels of currency risk. This risk is higher for banks that borrow and/or lend in foreign currency, as this may result in open currency positions or maturity mismatches. According to Bohachova (2008), the effect of exchange rate fluctuations on bank risk is dependent on a bank's foreign currency exposure, whereby a domestic currency depreciation can be expected to adversely affect banks whose foreign currency liabilities substantially exceed their foreign currency assets. However, it is the effect of exchange rate levels on the performance of bank borrowers that generally has the primary effect on bank profitability (i.e., the resulting increase in credit risk). On aggregate, a domestic currency depreciation is likely to increase the credit risk for bank loans extended to importers and decrease the credit risk of the exporting sector.

Dunn and Mutti (2004) explained that many governments prefer fixed exchange rates because they encourage price stability. They also prefer an independent monetary policy that can be used to minimize problems arising from domestic business cycles, and they value free capital mobility because it may result in large capital inflows that can accelerate economic growth. However, they point out that according to the impossible trinity proposition trilemma- in international monetary economics, these three goals cannot all be reached; any two may be available, but the third must be abandoned. O'Connell et al. (2010) explained that Kenya's Vision 2030 anticipates a substantial increase in external capital flows and that one of the key challenges resulting from enlisting foreign capital inflows in support of Vision 2030 projects is the trade-off between internal (maintaining macroeconomic stability) and external (supporting export competitiveness) policy objectives in the context of large capital inflows. However, their study found that though capital mobility in Kenya is substantial, it is not perfect. Consequently, they concluded that the Central Bank of Kenya still has some "limited scope for pursuing interest rate and exchange rate objectives simultaneously."

Empirically, Weller (2001) found that the vulnerability of emerging economies to currency and banking crises increases after capital account liberalization. This, he explains, is because capital account liberalization allows more liquidity to enter an emerging economy, which then finds its way into both productive and speculative projects due to internal financial liberalization. He further explains that in emerging economies where excess credit is observed, increased liquidity is mostly invested in speculative projects due to rising investor confidence and optimism that favors increasingly speculative financing. This growing trend of speculative financing increases the divergence between the real and the financial sectors, thereby increasing the likelihood of a crisis due to borrower default and the resulting capital outflows.

From the literature reviewed, it is evident that banks are exposed to various macroeco- 
nomic shocks and that market structure has the potential to either amplify or dampen the effects of these macroeconomic shocks on banking risk. In addition, it is also evident that macroeconomic shocks tend to be correlated. Hellwig (1998) pointed out that financial risks in banking are also correlated with each other since they are driven by common underlying factors. Such exposure was responsible for the American savings and loans crisis after deregulation in the 1980s and the various banking crises during the 1990s in Latin American, Scandinavian, and South East Asian countries. Locally, the aftermath of the currency crisis in 2011 confirmed that a rise in market interest rates increases market risk exposure, liquidity risk exposure, credit risk exposure, and eventually capital risk exposure.

\section{Methodology}

In banking, the volatility of net cash flows results from the expected and unexpected losses arising from the principal activities of lending and borrowing. In this study, the risk adjusted return on assets (RAROA) will be used to analyze banking risk exposure to the two activities. As pointed out by Hannagan (2007), the RAROA provides an economic view of bank earnings performance by adjusting for the opportunity cost of risk associated with holding the assets. In addition, the RAROA is a commonly used measure of bank performance used for internal reporting that captures the effect of both lending and borrowing risks. The use of this analytical framework is also based on similar studies (Gurbuz et al., 2013; Kohler, 2014) that have used this and other similar risk-adjusted performance measures:

$$
R A R O A=\frac{E P}{T A}=\frac{P A T-E L}{T A}
$$

where EP denotes economic profit, TA total assets, PAT profit after tax, and EL expected loss. $^{2}$ The risk associated with lending activities usually takes time to materialize, even though it may be affected by the same macroeconomic risks as the risk associated with borrowing activities. Thus the RAROA cannot capture the effect of both risks following a change in macroeconomic conditions in a specific year. Therefore, the RAROA is broken down into its key income and expense components to derive the two risk measures that will be used to separately analyze the two risks:

$$
R A R O A=\frac{N I I}{T A}+\frac{N I R}{T A}-\frac{O P E X}{T A}-\frac{N P L P}{T A}-\frac{E L}{T A}-\frac{T X}{T A}
$$

where NII denotes net interest income, NIR non-interest revenue, OPEX operating expenses, NPLP non-performing loans provision, and TX taxes paid. The risk associated with borrow-

\footnotetext{
${ }^{2}$ Expected loss is captured by statutory loan loss reserve and financial assets revaluation reserve.
} 
ing activities affects the net interest margin (NIM), while the risk associated with lending activities affects the non-performing loans (NPLs) and expected loss. These three components are exposed to macroeconomic risks and market competition pressures, while the other three components tend to be within the control of bank management. Non-interest revenue is sometimes exposed to macroeconomic risks because it is made up of foreign exchange trading revenue. Therefore, bank risk exposure will be measured by change in NIM $\left(\frac{N I I}{T R W A}\right)$ and change in lending risk exposure (LRE). ${ }^{3}$ Where LRE is calculated as the logarithm of the sum of non-performing loans and expected loss (the logarithmic transformation of the data is done to reduce skewness and heteroskedasticity). The net interest margin is calculated using total risk weighted assets (TRWA) instead of total assets because, as pointed out by Peng et al. (2003), TRWA captures interest earning assets and avoids distortions in NIM due to changes in other assets resulting from valuation effects.

The use of NPL instead of NPLP to measure risk exposure to lending activities is due to the fact that a bank's decision to make provisions for bad loans is often discretionary and partially motivated by capital adequacy considerations. The choice of this risk measure is also based on the finding by Rajan (1994) that banks generally charge-off loans (when losses are realized) which reduces loan loss reserves or add to reserves (when the potential for losses are recognized). This reduces earnings, but only when such actions are anticipated by the market. In addition, he also found that banks' provisions/charge-offs are also influenced by the provisions/charge-offs of other banks in the same lines of business. Therefore, he concluded that voluntary loan loss provisions and charge-offs will tend to have limited information effects.

The use of LRE instead of the NPL ratio to measure risk exposure to lending activities is due to the fact that several studies (Serwa, 2013; Coelho and Vivan, 2013) have found that the standard NPL ratio may vary in time for reasons not directly related to credit risks. Some of these reasons include rapid credit growth and the time a loan remains in the NPL condition (before being renegotiated, regularized or written-off). Therefore, modifications in the level of credit risk may be offset by movements in any of these other factors and can be concealed or amplified, which in turn could make the NPL ratio pro-cyclical. Consequently, several adjustments to the standard NPL ratio (that control for changes in credit growth and fluctuations in the term structure of bank loans) have been proposed for countries with rapidly developing banking sectors (such as Kenya). However, these adjustments require data on individual bank loan portfolios that was not readily available.

\footnotetext{
${ }^{3}$ The use of these dependent variables is based on similar studies by Gerlach et al. (2004), Gurbuz et al. (2013) and Ramayandi et al. (2014)
} 


\subsection{Data and Model Specification}

The aim of this research study is to analyze the effect of macroeconomic shocks and the changing market structure on banking risk in Kenya by estimating the following equation:

$$
R_{i t}=\delta R_{i, t-1}+\beta_{1} X_{i t}+\beta_{2} Y_{t}+\beta_{3} Z_{t}+\eta_{i}+\varepsilon_{i t}
$$

where $R_{i t}$ is a vector of observations on the bank risk measure of bank $i$ at time $t, R_{i, t-1}$ is the lagged bank risk variable, $X_{i t}$ is a vector of time-varying bank-specific control variables, $Y_{t}$ is a vector of time-varying macroeconomic variables, $Z_{t}$ is a vector of time-varying market structure variables, $\eta_{i}$ are the unobservable bank-specific effects, the $\beta^{\prime} s$ are coefficients of the fixed effects that are estimated across banks, $\delta$ is the coefficient of the lagged bank risk variable and $\varepsilon_{i t}$ is the disturbance term. This model specification follows similar specifications by Gerlach et al. (2004), Gurbuz et al. (2013), and Ramayandi et al. (2014).

The following model specification is used to investigate the determinants of risk exposure associated with borrowing activities:

$$
\begin{aligned}
N I M_{i t} & =\delta N I M_{i, t-1}+\beta_{1} M S H A R E_{i t}+\beta_{2} D I V E R S E_{i, t-k}+\beta_{3} L T A_{i, t-k} \\
& +\beta_{4} C O N C_{t}+\beta_{5} M S I Z E_{t}+\beta_{6} R G D P G_{t}+\beta_{7} I N T_{t}+\beta_{8} I N F L_{t}+\beta_{9} E R_{t} \\
& +\beta_{10} N C F_{t}+\eta_{i}+\varepsilon_{i t}
\end{aligned}
$$

The following model specification is used to investigate the determinants of risk exposure associated with lending activities: ${ }^{4}$

$$
\begin{aligned}
& \ln L R E_{i t}=\delta \ln L R E_{i, t-1}+\beta_{1} M S H A R E_{i t}+\beta_{2} \ln L O A N_{i, t-k}+\beta_{3} C A R_{i, t-k} \\
& +\beta_{4} C O N C_{t-1}+\beta_{5} M S I Z E_{t-1}+\beta_{6} R G D P G_{t-1}+\beta_{7} I N T_{t-1}+\beta_{8} I N F L_{t-1} \\
& +\beta_{9} E R_{t-1}+\beta_{10} N C F_{t-1}+\eta_{i}+\varepsilon_{i t}
\end{aligned}
$$

The market structure variables are defined as follows:

- The degree of concentration (CONC) in the banking sector is measured by the percentage share of the assets of the three largest banks in total banking assets for year $t$. Banks that experience less competition (a high degree of concentration) should theoretically be more risk averse (Hellman et al., 2000).

- The size of the banking market (MSIZE) is measured as the share of domestic credit to the private sector relative to GDP for year $t$. It will be used as a measure for both financial development and the degree of leverage in the economy. The expected effect

\footnotetext{
${ }^{4}$ The dynamics of both models will be determined by trying out several lags and then removing the nonsignificant lags.
} 
is not clear - the more financially developed the country is, the lower we anticipate the volatility of macroeconomic variables. The higher the credit ratio, the larger the multiplier effects of a given economic shock (Bremus and Buch, 2015).

Both of the market structure variables enter the LRE equation with a lag to account for the delay with which the changing market structure affects a bank's credit portfolio. The macroeconomic variables used here are based on the discussion in sub-section 1.2 and are defined as follows: ${ }^{5}$

- The annual rate of growth of real GDP (RGDPG) for year $t$ is used as a measure of the business cycle conditions - banking risks increase as the economic conditions worsen.

- The average rate on 91-day treasury bills (INT) for year $t$ is used as a proxy for the short-term interest rate levels. The expected effect on borrowing risk exposure is negative but positive for lending risk exposure.

- The annual inflation rate (INFL), the USD and EUR exchange rate (ER) changes, and the annual net capital flows (NCF) for year $t$ are also included in the model as explanatory variables. The more volatile the inflation rate and exchange rates the higher the risk exposure. The volatility of net capital flows generally depends on the volatility of the inflation rate and the exchange rates.

All of the macroeconomic variables enter the LRE equation with a lag to account for the delay with which macroeconomic shocks affect a bank's credit portfolio. The following bank-specific control variables are used:

- The bank's market share of total banking assets (MSHARE) for bank $i$ in year $t$ is included to proxy for bank size. Large banks are less risky because they are more diversified and have better risk screening models. However, they also enjoy a too big to fail subsidy that may increase their risk-taking incentives (Bremus and Buch, 2015).

- The loans to total assets ratio (LTA) for bank $i$ in year $t$ is used to control for the choices made by bank managers for riskier investments compared to holding government securities. A higher proportion of assets allocated to loans increases credit risk exposure at banks and may therefore result in more problem loans that increase fluctuations in interest income (Love and Ariss, 2013).

- The rate of loan growth (LOG.LOAN) for bank $i$ in year $t$ is used to control for credit portfolio growth. Excessive credit growth fills the bank's balance sheet with more risky assets (Gurbuz et al., 2013).

\footnotetext{
${ }^{5}$ See Figure 1 for time-series charts of the macroeconomic data used.
} 
- The degree of functional diversification (DIVERSE) for bank $i$ in year $t$ is measured by calculating the share of a bank's non-interest revenue in its total operating revenue. A high ratio of non-interest income improves risk diversification by making banks less dependent on interest income. Non-interest income is usually more volatile than interest income because it is usually more difficult for borrowers to switch their lending relationships (Kohler, 2014).

- The capital adequacy ratio (CAR) for bank $i$ in year $t$ is used to control for the bank's risk profile. Banks with riskier loan portfolios may need higher capital buffers to insure against the resulting credit risks (Bohachova, 2008; Bremus and Buch, 2015).

Banks that grow faster are more likely to increase their exposure to risky assets. Therefore all of the bank-specific variables (with the exception of market share) enter the LRE equation with a lag to account for the delay with which idiosyncratic shocks affect banks' credit portfolios.

Data on market structure variables will be obtained from the CBK Bank Supervision Annual Reports, data on macroeconomic variables will be obtained from the economic surveys and CBK Rates, and data on the bank-specific variables will be obtained from their annual financial statements. The bank sample is drawn from banks that have end-of-year information for the period 2008 to 2013. The bank sample was made up of 32 out of the 43 banks operating at the end of 2013, which accounted for about $95 \%$ of the total banking assets.

\subsection{Model Estimation}

In equation 1 , the lagged bank risk variable is included as an explanatory variable. Ramayandi et al. (2014) explained that the persistence of the bank risk variable may reflect the existence of intense competition or the pro-cyclical risk-taking behaviour in line with the business cycle dynamics. The coefficient of the lagged bank risk variable is viewed as the speed of convergence to equilibrium. A statistically significant value of zero implies that bank risk is characterized by a high speed of adjustment, while a value of one means that the adjustment is very slow, and values between zero and one suggest that risk persists but will eventually return to its mean. Consequently, a static model would be biased if bank risk is persistent.

To resolve the estimation problem caused by using the lagged dependent variable as an explanatory variable, the generalized method of moments (GMM) procedure proposed by Arellano and Bond (1991) will be used because it leads to consistent and efficient estimates by using the dynamic endogeneity inherent in the explanatory variables (i.e., lags of endogenous variables) as instruments. ${ }^{6}$ Heij et al. (2004) explained that the GMM procedure derives

\footnotetext{
${ }^{6}$ The risk measure in equation 1 is explained by past values (one lag) of the risk measure; therefore, all lags of this explanatory variable beyond lag one will be used as instruments.
} 
parameter estimates by equating sample moments to unobserved population moments with the assumed statistical distribution and then solving the equations. The first differenced GMM estimator vector is derived as:

$$
\hat{\beta^{e}}=\left[\left(\sum_{i=1}^{N}\left(\triangle x_{i,-1}^{e}\right)^{\prime} Z_{i}\right) W_{N}\left(\sum_{i=1}^{N} Z_{i}^{\prime} \triangle x_{i,-1}^{e}\right)\right]^{-1} \times\left[\left(\sum_{i=1}^{N}\left(\triangle x_{i,-1}^{e}\right)^{\prime} Z_{i}\right) W_{N}\left(\sum_{i=1}^{N} Z_{i}^{\prime} \triangle y_{i}\right)\right]
$$

where $Z_{i}$ is the instrument matrix, $W_{N}$ is the weight matrix and the exogenous independent variables are defined as:

$$
\beta^{e}=\left[\begin{array}{c}
\delta \\
\beta_{1} \\
\vdots \\
\beta_{k}
\end{array}\right] \text { and } x_{i,-1}^{e}=\left[\begin{array}{cccc}
y_{i, 2} & x_{1, i, 1} & \ldots & x_{k, i, 1} \\
\vdots & \vdots & \ddots & \vdots \\
y_{i, T-1} & x_{1, i, T-2} & \ldots & x_{k, i, T-2}
\end{array}\right]
$$

To complement the GMM multivariate analysis and identify the key determinants of risk persistence, a panel vector-autoregression (PVAR) model will be used. The PVAR framework is ideal for this purpose because it simultaneously takes into account interactions between all the macroeconomic variables and bank-specific variables in the model, unlike the separate model specifications used in the GMM multivariate analysis to control for possible multicolinearity of the macroeconomic variables. If there are no unit roots in the underlying time series, GMM estimators can be used to estimate the PVAR model coefficients.

Pfaff (2008) explained that the basic vector auto-regression (VAR) model consists of a set of $\mathrm{K}$ endogenous variables $y_{t}=\left(y_{1 t}, \ldots, y_{k t}\right)$ for $\mathrm{k}=1, \ldots, \mathrm{K}$ and that the $\operatorname{VAR}(p)$ process is defined as:

$$
y_{t}=A_{1} y_{t-1}+\ldots+A_{p} y_{t-p}+C D_{t}+u_{t}
$$

where $A_{i}$ are $(K \times K)$ coefficient matrices for $\mathrm{i}=1, \ldots, p$ and $u_{t}$ is a $\mathrm{K}$ dimensional white noise process. The matrix $\mathrm{C}$ is the coefficient matrix of potentially deterministic regressors with dimension $(K \times M)$, and $D_{t}$ is an $(M \times 1)$ column vector holding the appropriate deterministic regressors such as a constant, trend, and/or dummy variables. Canova and Ciccarelli (2013) explained that PVAR models are built on the same structure as VAR models (all variables are assumed to be endogenous and interdependent), with a cross sectional dimension included that makes them well suited for analyzing the transmission of shocks across units and time. Therefore, following Love and Ariss (2013), the PVAR model used to identify the transmission of macroeconomic shocks is defined as:

$$
y_{i t}=U_{i}+A(L) y_{i t}+e_{i t}
$$


where $\mathrm{A}(\mathrm{L})$ is the lag operator, $U_{i}$ is used to control for unobserved bank heterogeneity and $y_{i t}$ is a vector of macroeconomic and bank-specific variables. Variables that enter first in equation 6 are assumed to be the most exogenous and hence affect subsequent variables both contemporaneously and with a lag. Variables that are ordered later are less exogenous and affect previous variables only with a lag. System GMM is used to estimate the coefficients of the PVAR model.

\section{Results}

\subsection{Descriptive Statistics}

The descriptive statistics of the variables used in the study are summarized in Table 1 . The bank sample shows a large variability in bank size as measured by market share (MSHARE) and a large variability in bank risk profile as measured by the capital adequacy ratio (CAR), which minimize the potential of sample selection bias. The variability in the bank sample is captured in more detail in the bank descriptive statistics in Table $2{ }^{7}$

\subsection{Correlation Analysis}

Macroeconomic variables are not independent, and therefore multicolinearity may be a problem when using these variables in the same regression equation. Table 3 shows that some of the macroeconomic variables that will be used in the study are highly correlated; thus, multicolinearity is indeed a problem. Though their interdependence reinforces their individual influence on bank risk, it can also make an empirical assessment of their relative importance for bank risk exposure difficult. Additional regressions will be run so that the macroeconomic variables can be included in separate model specifications.

\subsection{Panel Unit Root Tests}

Panel unit root tests help evaluate the time series property of the data accordingly thus avoiding contradictory results in individual time series. The first two tests will be the augmented Dickey-Fuller (ADF) test and the Phillips-Perron (PP) test. Two other tests - the Elliott-Rothenberg-Stock (ERS) test and the Schmidt-Phillips (SP) test - will also be carried out to address a common shortcoming with the first two tests. Pfaff (2008) explained that the common shortcoming of the ADF and PP tests is their relatively low power if the true data-generating process is an AR (1) process with a coefficient close to one, due to the fact that a unit root process is specified as the null hypothesis.

\footnotetext{
${ }^{7}$ Large: Total assets market share exceeds 5\%; Medium: Between $1 \%$ and 5\%; Small: Less than $1 \%$
} 
Table 4 presents the results of the panel unit root tests. All the tests reject the presence of unit roots in the panel. However, (MSHARE), (CTI), and (ROE) are not significant at the $1 \%$ level, probably due to the effects of rising competition and growing market size on the market shares, managerial efficiency, and shareholder returns at some of the banks.

\subsection{Robustness Checks}

The validity of the results for all the model specifications is confirmed by the various model diagnostic tests used to evaluate whether the data are consistent with the assumptions of dynamic panel data models. The results are presented in the bottom rows of Table 7 and 8 .

The Sargan test of over-identifying restrictions meets the requirement of failing to reject the null hypothesis that the instruments are not correlated with the errors in the firstdifferenced equation. The AR (1) and AR (2) tests meet the requirements of rejecting the null hypothesis of no first-order serial correlation but fails to reject the null hypothesis of no second-order serial correlation in first-differenced errors. Therefore, the validity of the instruments is guaranteed under the hypothesis that the error terms are not second-order serially correlated. In addition, the results of the Wald test of joint significance show that the coefficients are jointly significant.

\subsection{Empirical Results}

The empirical analysis proceeds in three steps. The first step involves running a baseline fixed effects regression for the bank-specific control variables. The second step involves running a GMM regression for the borrowing and lending risk exposure models, and the final step involves analyzing the key variables contributing to risk persistence by using a PVAR model to interact the significant variables from the risk exposure models.

Table 5 and 6 present the baseline regression results. The purpose of the baseline specifications is to estimate the within effect of bank-specific control variables on bank risk exposure before conducting regression with the market structure and macroeconomic variables. The large group comprises banks with a market share of total assets in excess of $5 \%$ each, those in the medium-sized group have a market share of between $1 \%$ to $5 \%$, and those in the small group have a market share of less than $1 \%$.

Table 7 and 8 present the GMM regression results for the NIM model and LRE model respectively. The different columns indicate the separate model specifications for the macroeconomic variables, whereby the macroeconomic variables are included separately to avoid the problems of multicolinearity. 


\subsubsection{Net Interest Margin}

The baseline regression results for all banks in Table 5 indicate a negative and statistically significant estimate for the borrowing risk persistence measure. However, the relationship only applies to small banks which may imply that increased competition in the deposit market is reducing their margins. Nevertheless, this result justifies the choice of a dynamic model. The F-statistic for the large banks model is comparatively smaller and statistically insignificant, which indicates that the regression coefficients are not jointly significant due to a high ratio of unexplained variance. Therefore, this may imply that the effect of macroeconomic and/or market structure variables is more important in explaining the borrowing risk exposure of large banks. The GMM regression results in Table 7 indicate that borrowing risk exposure is not persistent, which may reflect the increased competition (i.e., a high speed of adjustment) in the deposit market.

The degree of concentration (CONC) was found to have a positive effect which implies that increased competition in the deposit market reduces the franchise value of banks by reducing the NIM. The size of the banking market (MSIZE) was also found to have a positive effect, which implies that the higher the credit ratio, the higher the volatility of a given economic shock (in this case the inflation rate, USD exchange rate, and EUR exchange rate). A higher credit ratio implies higher leverage in the economy, which implies larger multiplier effects.

The loan to assets ratio (LTA) was found to have a negative effect that also holds for the previous period's loan to assets ratio. This implies that an increase in the size of the proportion of loans (at medium-sized and small banks, see Table 5) tends to reduce the NIM in the current and following year, probably because the higher liquidity requirements following credit expansion and/or the resulting rise in NPLs increases funding costs. This result is similar to the finding by Love and Ariss (2013) that banks in Egypt with a higher proportion of assets allocated to loans also had higher credit risk exposure, and the resulting problem loans increased fluctuations in interest income. Market share (MSHARE) has no effect and this is consistent with the findings of Bremus and Buch (2015) - bank size does not matter for idiosyncratic fluctuations of banks in low-income countries because the return on assets does not reduce bank-level risk.

The inflation rate (INFL) was found to have a negative effect, which implies that rising inflation increases borrowing risk exposure (reduces NIM). This is consistent with the findings of Ndebbio (2004), who stated that rising rates of inflation tend to induce disintermediation by causing economic agents to hold other assets such as land, physical goods, gold, and foreign currency in preference to domestic currency. Changes in the exchange rates (USD and EUR) were also found to have a negative effect, which implies that depreciation of the domestic currency increases borrowing risk exposure (reduces NIM). The results also indicate that changes in the short-term interest rate (INT) have no effect, which may imply that bank 
deposit and lending rates are rigid. The interest rate channel in Kenya was found to be ineffective (Misati et al., 2011; Mahasi and Pokhariyal, 2013) because it took between 10 to 24 months to fully transmit monetary policy shocks to the lending and deposit rates. In South Africa, Aziakpono and Wilson (2010) found that banks were more rigid in adjusting their lending rates and deposit rates upward in response to a positive shock in the official rate, thus providing support for the adverse customer reaction hypothesis and the collusive behaviour hypothesis respectively. In Hong Kong, Peng et al. (2003) found that changes in the short-term interest rate had no impact on the intermediation spread.

\subsubsection{Lending Risk Exposure}

The baseline regression results for all banks in Table 6 indicate a positive and statistically significant estimate for the lending risk persistence measure. The relationship only applies to small and medium-sized banks, but nevertheless justifies the choice of a dynamic model. The GMM regression results in Table 8 also indicate that lending risk exposure is persistent; however, the coefficient is less than one, which means that lending risk exposure will eventually return to its mean. The results also suggest that all the macroeconomic variables used are significant determinants of lending risk exposure for banks in Kenya.

The degree of concentration (CONC) was found to have a positive effect, which implies that reduced competition in the loan market increases the lending risk exposure. The degree of concentration has been declining during the study period; therefore, the positive relationship does not support the franchise value paradigm where the decline in franchise value resulting from competition is expected to lower incentives for making good loans. Therefore, the results imply that bank competition in the loan market increases banking stability. The size of the banking market (MSIZE) was found to have a negative effect, which implies that a larger banking market provides more opportunities to diversify risk. This effect is explained by Bremus and Buch (2015) who stated that the more financially developed a country is, the lower is the volatility of a given economic shock (in this case, the positive shock of net capital flows).

The loan growth rate (LOG.LOAN) was found to have a positive effect, which implies that rapid credit growth (at large and medium-sized banks, see Table 6) fills the bank's balance sheet with more risks. Greuning and Bratanovic (2003) found that rapid credit growth increases credit risk when the bank fails to match its growing loan portfolio with adequate credit risk management capacity. Love and Ariss (2013) found that the effect was due to the relationship between rapid loan growth and adverse selection, which reduces asset quality.

The real GDP growth rate (RGDPG) was found to have a negative effect, which implies that an improvement in economic conditions reduces lending risk exposure in the following 
period. All the other macroeconomic variables were found to have a positive effect on the following period lending risk exposure, which implies that a sharp rise in their values impairs the quality of previously extended loans. Though the estimated coefficient for net capital flows $(\mathrm{NCF})$ is marginal, the positive relationship may imply that an increase in foreign borrowing may give rise to misallocation of funds and over-investment in the non-tradeable sectors that increases lending risk exposure. ${ }^{8}$ This is consistent with the findings of Hansanti et al. (2008). Following financial liberalization in Thailand, both FDI and portfolio inflows switched from industry and trade to the non-tradeable sectors (real estate, short-term loans, and portfolio investments) that were not generating foreign exchange earnings to service the foreign debt. This led to the creation of an asset-price bubble. Similarly, Beck et al. (2013) found that exchange rate depreciations lead to an increase of non-performing loans in countries with a high degree of lending in foreign currencies to unhedged borrowers. Specifically, they found that the depreciation of local currencies against the Swiss Franc and the Euro - in Poland, Hungary, and Croatia where lending in these currencies was widespread - negatively affected bank asset quality via negative balance sheet effects.

\subsubsection{Analysis of Risk Persistence}

The focus of this study was to analyze the impact of the factors affecting banks' borrowing and lending risk exposure. From the results presented in the preceding sub-sections, it is evident that lending risk exposure is persistent and therefore requires further analysis. This section uses a PVAR model to analyze how the key variables affect lending risk exposure. The PVAR model specification considers three significant macroeconomic variables (real GDP growth rate, short-term interest rate, and the USD/KES exchange rate) and three bank-specific variables (lending risk exposure, loan growth rate, and capital adequacy ratio). Variables that enter first in the PVAR model (equation 6) are assumed to be the most exogenous and hence affect subsequent variables both contemporaneously and with a lag. Variables that are ordered later are less exogenous and affect previous variables only with a lag.

The original shock is assumed to come from changes in the USD exchange rate, which has a contemporaneous effect on the real GDP growth rate, short-term interest rate, and all bank-specific variables. All the other variables affect the USD exchange rate with a lag. For the bank-specific variables, the shock is assumed to come from changes in the lending risk exposure, which affects the loan growth rate and capital adequacy ratio contemporaneously. The loan growth rate and capital adequacy ratio affect the lending risk exposure with a

\footnotetext{
${ }^{8}$ There has been a growing trend of commercial banks borrowing from foreign financial institutions to meet the rising domestic financing requirements, and this is contributing to the declining trend in commercial banks' net foreign asset position - from a credit balance of KES 50 billion in December 2007 to a debit of KES 109 billion in December 2014. (Source: CBK Depository Corporation Survey)
} 
lag. Love and Ariss (2013) explained that due to the fact that all macroeconomic variables are entered first into the system, they have an immediate effect on bank-specific variables. Feedback from bank-specific variables on macroeconomic variables occurs only with a lag.

Table 9 presents the estimation results showing that most coefficients are found to be statistically significant. From the PVAR results, the key variables affecting the persistence of lending risk exposure are the previous period's loan growth rate and interest rate. They are both positively related with lending risk exposure and the estimated direct effects are 0.075 and 0.037, respectively. Therefore, this implies that bank risk taking at some of the mediumsized and small banks is the key determinant of the persistence of lending risk exposure (see Figures 2 and 3).

There are various factors that influence excessive risk taking by banks. However, several studies (Johnson, 1994; Godlewski, 2007; Abdellaoui et al., 2013) have all found that prospect theory best explains risk-taking decisions that increase risk exposure in banking, such as increased risk taking due to negative or declining returns. Prospect theory, which was developed by Kahneman and Tversky (1979), states that the tendency to over-weigh outcomes that are considered certain relative to outcomes that are probable (the certainty effect) contributes to risk aversion in choices involving sure gains and to risk seeking in choices involving sure losses. Therefore, following Johnson (1994), the risk-return trade-off for banks with above median ROE and below median ROE is depicted in Figure 3. Banks operating above the median ROE tend to cluster around the same level, and there are a couple of outliers for banks operating below the median ROE (especially medium-sized and small banks). This may indicate excessive risk taking in the face of negative or declining target returns. This tendency of excessive risk taking is also depicted in Figure 2, where the few banks with the highest loan growth rate also happen to have an NPL ratio that is above the median.

\section{Conclusions}

This paper investigated the effect of changing market structure and macroeconomic shocks on the borrowing and lending risk exposure of Kenyan commercial banks using a GMM estimation approach. Borrowing risk exposure was found not persistent, being mainly affected by the degree of concentration and external economic shocks. Interestingly, the results also suggest that changes in the short-term interest rate do not affect the net interest margin, which may imply that bank deposit and lending rates are rigid and that the interest rate channel may be ineffective. Lending risk exposure was found to be persistent, being mostly

affected by the degree of concentration, internal economic shocks, and external economic shocks. The positive relationship between the degree of concentration and both borrowing and lending risk exposure supports the concentration-fragility view - the declining franchise 
value did not lower incentives for making good loans during the study period where the degree of concentration was on a downward trend. Further analysis of the factors contributing to the persistence of lending risk exposure using a PVAR model found that the banks' loan growth rate and the market interest rate were the key determinants. The effect of the loan growth rate was about double the effect of interest rate risk, implying that bank risk taking at some of the medium-sized and small banks is the key determinant of the persistence of lending risk exposure.

These results have important implications as far as bank regulation is concerned. Specifically, the persistence of lending risk exposure can be reduced by improving the capacity of the regulator to monitor overall bank risk taking. The underlying risk posed by the declining net foreign assets of commercial banks due to foreign borrowing also needs to be monitored. This problem was identified by Taylor (1998) as having the potential to increase the overall risk of the financial system's balance sheet in the event of a currency depreciation by being long on domestic assets and short on foreign currency holdings.

The USD exchange rate was found to have a large negative effect the net interest margin. Therefore, the biggest threat to borrowing risk exposure is the USD exchange rate depreciation. According to Moore and Pentecost (2006), one possible mitigating measure involves distinguishing between permanent and transitory shocks on the exchange rate so as to avoid the potentially damaging attempt to stabilize exchange rate changes that are due to structural changes in the economy. This can result in an overvalued currency that can lead to a speculative attack. According to Agenor and da Silva (2013), another possible mitigating measure involves adopting an integrated inflation targeting framework that combines monetary policy with macro-prudential policies, whereby the policy interest rate is also set to respond directly to a pre-defined measure of the private sector credit growth gap, to jointly achieve macroeconomic and financial stability.

The real GDP growth rate was found to have a large negative effect on lending risk exposure. Therefore, the biggest threat to lending risk exposure is a negative shock in any of the key economic sectors. It is thus prudent for policy makers to continue monitoring the potential for such developments to ensure that the existing institutional structure can dampen such fluctuations and that timely mitigating measures can be implemented to reduce the persistence of the ensuing gap between actual and potential output.

\section{Acknowledgements}

My gratitude goes to Prof. Francis Mwega, Ms. Laura Barasa and to two anonymous referees for their insightful comments and suggestions during the research process. I acknowledge with thanks the helpful criticisms and suggestions from Dr. Bethuel Kinyanjui, Dr. Thomas 
Ongoro, Prof. Jane Mariara, Prof. Leopold Mureithi and Mr. George Macharia during the proposal presentation seminar. I am also grateful to Mr. E. P. Kipsitet, Mr. Luke Plapan and Ms. Irene Rugiri of the Central Bank of Kenya for facilitating the financial statement data collection process.

\section{References}

Abdellaoui, M., Bleichrodt, H., and Kammoun, H. (2013). Do financial professionals behave according to prospect theory? An experimental study. Theory and Decision, 74:411-429.

Acemoglu, D., Johnson, S., Robinson, J., and Thaicharoen, Y. (2003). Institutional causes, macroeconomic symptoms: Volatility, crises and growth. Journal of Monetary Economics, 50:49-123.

Agenor, P.-R. and da Silva, L. P. (2013). Inflation Targeting and Financial Stability: A Perspective from the Developing World. Banco Central do Brasil Working Paper. No 324.

Agenor, P.-R. and Montiel, P. J. (2008). Development Macroeconomics. Princeton, NJ: Princeton University Press, 3rd edition.

Agosin, M. R. and Huaita, F. (2011). Capital flows to emerging economies: Minsky in the tropics. Cambridge Journal of Economics, 35:663-683.

Allen, F., Babus, A., and Carletti, E. (2009). Financial Crises: Theory and Evidence. Annual Review of Financial Economics, 1:97-116.

Allen, F. and Gale, D. (2004). Competition and Financial Stability. Journal of Money, Credit and Banking, 36(3):453-480.

Arellano, M. and Bond, S. (1991). Some Tests of Specification for Panel Data: Monte Carlo Evidence and an Application to Employment Equations. Review of Economic Studies, $58(2): 277-297$.

Aziakpono, M. J. and Wilson, M. K. (2010). Interest Rate Pass-Through and Monetary Policy Regimes in South Africa. In Paper presented during the CSAE conference held at Oxford University from 21-23 March 2010.

Beck, R., Jakubik, P., and Piloiu, A. (2013). Non-performing loans: What matters in addition to the economic cycle? European Central Bank Working Paper. No 1515.

Bohachova, O. (2008). The impact of macroeconomic factors on risks in the banking sector: A cross-country empirical assessment. IAW Discussion Paper. No 44. 
Boyd, J. H. and De Nicolo, G. (2005). The Theory of Bank Risk Taking and Competition Revisited. Journal of Finance, 60(3):1329-1343.

Bremus, F. and Buch, C. M. (2015). Banking Market Structure and Macroeconomic Stability: Are Low Income Countries Special? Pacific Economic Review, 20(1):73-100.

Brownbridge, M. (1998). The Causes of Financial Distress in Local Banks in Africa and Implications for Prudential Policy. UNCTAD Discussion Paper. No 132.

Canova, F. and Ciccarelli, M. (2013). Panel Vector Autoregressive Models: A Survey. European Central Bank Working Paper. No 1507.

Central Bank of Kenya (2003). Bank Supervision Annual Report 2003. Nairobi: Central Bank of Kenya.

Coelho, R. L. P. and Vivan, G. F. A. (2013). Converting the NPL Ratio into a Comparable Long Term Metric. Banco Central do Brasil Working Paper. No 309.

Degryse, H. and Ongena, S. (2005). Competition and Regulation in the Banking Sector: A Review of the Empirical Evidence on the Sources of Bank Rents. Tilburg University, mimeo.

Demirguc-Kunt, A. and Detagiache, E. (1998). The Determinants of Banking Crises in Developing and Developed Countries. IMF Staff Papers, 45(1):81-109.

Demirguc-Kunt, A. and Detragiache, E. (2001). Financial Liberalization and Financial Fragility. In Caprio, G., Honohan, P., and Stiglitz, J. E., editors, Financial Liberalization: How Far, How Fast?, pages 96-122. New York: Cambridge University Press.

Dunn, R. M. and Mutti, J. H. (2004). International Economics. New York: Routledge, 6th edition.

Esch, L., Kieffer, R., and Lopez, T. (2005). Asset and Risk Management. West Sussex: Wiley.

Gerlach, S., Peng, W., and Shu, C. (2004). Macroeconomic Conditions and Banking Performance in Hong Kong: A Panel Data Study. HKMA Research Memorandum. No 05/2004.

Godlewski, C. J. (2007). An Empirical Investigation of Bank Risk-Taking in Emerging Markets within a Prospect Theory Framework. Banks and Bank Systems, 2(2):35-43.

Goodhart, C., Hofmann, B., and Segoviano, M. (2004). Bank Regulation and Macroeconomic Fluctuations. Oxford Review of Economic Policy, 20(4):591-615. 
Government of Kenya (2007). Kenya Vision 2030. Nairobi: Government of Kenya.

Greuning, H. V. and Bratanovic, S. B. (2003). Analyzing and Managing Banking Risk. Washington, D.C.: International Bank for Reconstruction and Development, 2nd edition.

Gurbuz, A. O., Yanik, S., and Ayturk, Y. (2013). Income Diversification and Bank Performance: Evidence from Turkish Banking Sector. BDDK Bankacilik ve Finansal Piyasalar, $7(1): 9-29$.

Hannagan, T. A. (2007). Capital-Based Profitability Measurement. Bank Accounting and Finance, pages 21-28. August-September.

Hansanti, S., Islam, S. M. N., and Sheehan, P. (2008). International Finance in Emerging Markets. Heidelberg: Physica-Verlag.

Hausmann, R. and Gavin, M. (1996). Securing Stability and Growth in a Shock Prone Region: The Policy Challenge for Latin America. Inter-American Development Bank Working Paper. No 315.

Heffernan, S. (2005). Modern Banking. West Sussex: Wiley.

Heij, C., de Boer, P., Franses, P. H., Kloek, T., and van Dijk, H. K. (2004). Econometric Methods with Applications in Business and Economics. Oxford: Oxford University Press.

Hellman, T. F., Murdock, K. C., and Stiglitz, J. E. (2000). Liberalization, Moral Hazard in Banking, and Prudential Regulation: Are Capital Requirements Enough? American Economic Review, 90(1):147-165.

Hellwig, M. (1995). Systemic Aspects of Risk Management in Banking and Finance. Swiss Journal of Economics and Statistics, 131(4):723-737.

Hellwig, M. (1998). Banks, Markets, and the Allocation of Risk in an Economy. Journal of Institutional and Theoretical Economics, 154:328-351.

Johnson, H. J. (1994). Prospect Theory in the Commercial Banking Industry. Journal of Financial and Strategic Decisions, 7(1):73-89.

Kahneman, D. and Tversky, A. (1979). Prospect Theory: An Analysis of Decision under Risk. Econometrica, 47(2):263-292.

Kilishi, A. A., Mobolaji, H. I., Yaru, M. A., and Yakubu, A. T. (2013). Institutions and Economic Performance in Sub-Saharan Africa: A Dynamic Panel Data Analysis. Journal of African Development, 15(2):91-119. 
Kohler, M. (2014). Does non-interest income make banks more risky? Retail versus investment-oriented banks. Review of Financial Economics, 23(4):182-193.

Laeven, L. (2011). Banking Crises: A Review. Annual Review of Financial Economics, $3: 17-40$.

Love, I. and Ariss, R. T. (2013). Macro-Financial Linkages in Egypt: A Panel Analysis of Economic Shocks and Loan Portfolio Quality. IMF Working Paper. No WP/13/271.

Mahasi, J. and Pokhariyal, G. P. (2013). Two Stage Interest Rate Pass Through in Kenya. Journal of Emerging Trends in Economics and Management Sciences, 4(1):54-61.

Misati, R. N., Nyamongo, E. M., and Kamau, A. W. (2011). Interest rate pass-through in Kenya. International Journal of Development Issues, 10(2):170-182.

Misati, R. N., Nyamongo, E. M., and Mwangi, I. (2013). Commodity price shocks and inflation in a net oil-importing economy. OPEC Energy Review, 37(2):125-148.

Moore, T. and Pentecost, E. J. (2006). The Sources of Real Exchange Rate Fluctuations in India. Indian Economic Review, 41(1):9-23.

Mwega, F. M. (2011). The Competitiveness and Efficiency of the Financial Services Sector in Africa: A Case Study of Kenya. African Development Review, 23(1):44-59.

Ndebbio, J. E. U. (2004). Financial deepening, economic growth and development: Evidence from selected Sub-Saharan African countries. AERC Research Paper. No 142.

Ngugi, R. W. and Kabubo, J. W. (1998). Financial sector reforms and interest rate liberalization: The Kenya experience. AERC Research Paper. No 72.

Nkurunziza, J. D. (2005). Credit Can Precipitate Firm Failure: Evidence from Kenyan Manufacturing in the 1990s. CSAE Working Paper. No WPS/2005-04.

O’Connell, S. A., Maturu, B. O., Mwega, F. M., Ndung'u, N. S., and Ngugi, R. W. (2010). Capital mobility, monetary policy, and exchange rate management in Kenya. In Adam, C. S., Collier, P., and Ndung'u, N., editors, Kenya: Policies for Prosperity, pages 172-208. Oxford: Oxford University Press.

Odhiambo, N. M. (2012). The Impact of Inflation on Financial Sector Development: Experience from Zambia. Journal of Applied Business Research, 28(6):1497-1508.

Peng, W., Lai, K., Leung, F., and Shu, C. (2003). The Impact of Interest Rate Shocks on the Performance of the Banking Sector. HKMA Research Memorandum. No 07/2003. 
Pfaff, B. (2008). Analysis of Integrated and Cointegrated Time Series with R. New York: Springer.

Rajan, R. G. (1994). Why Bank Credit Policies Fluctuate: A Theory and Some Evidence. Quarterly Journal of Economics, 109(2):399-441.

Ramayandi, A., Rawat, U., and Tang, H. C. (2014). Can Low Interest Rates be Harmful: An Assessment of the Bank Risk-Taking Channel in Asia. Asian Development Bank Working Paper. No 123.

Serwa, D. (2013). Measuring non-performing loans during (and after) credit booms. Central European Journal of Economic Modelling and Econometrics, 5:163-183.

Stiglitz, J. E. and Weiss, A. (1981). Credit Rationing in Markets with Imperfect Information. American Economic Review, 71(3):393-410.

Taylor, L. (1998). Lax Public Sector, Destabilizing Private Sector: Origins of Capital Market Crises. CEPA Working Paper. No 6.

Weller, C. E. (2001). Financial Crises After Financial Liberalisation: Exceptional Circumstances or Structural Weakness? Journal of Development Studies, 38(1):98-127. 
Figure 1: Macroeconomic Variables
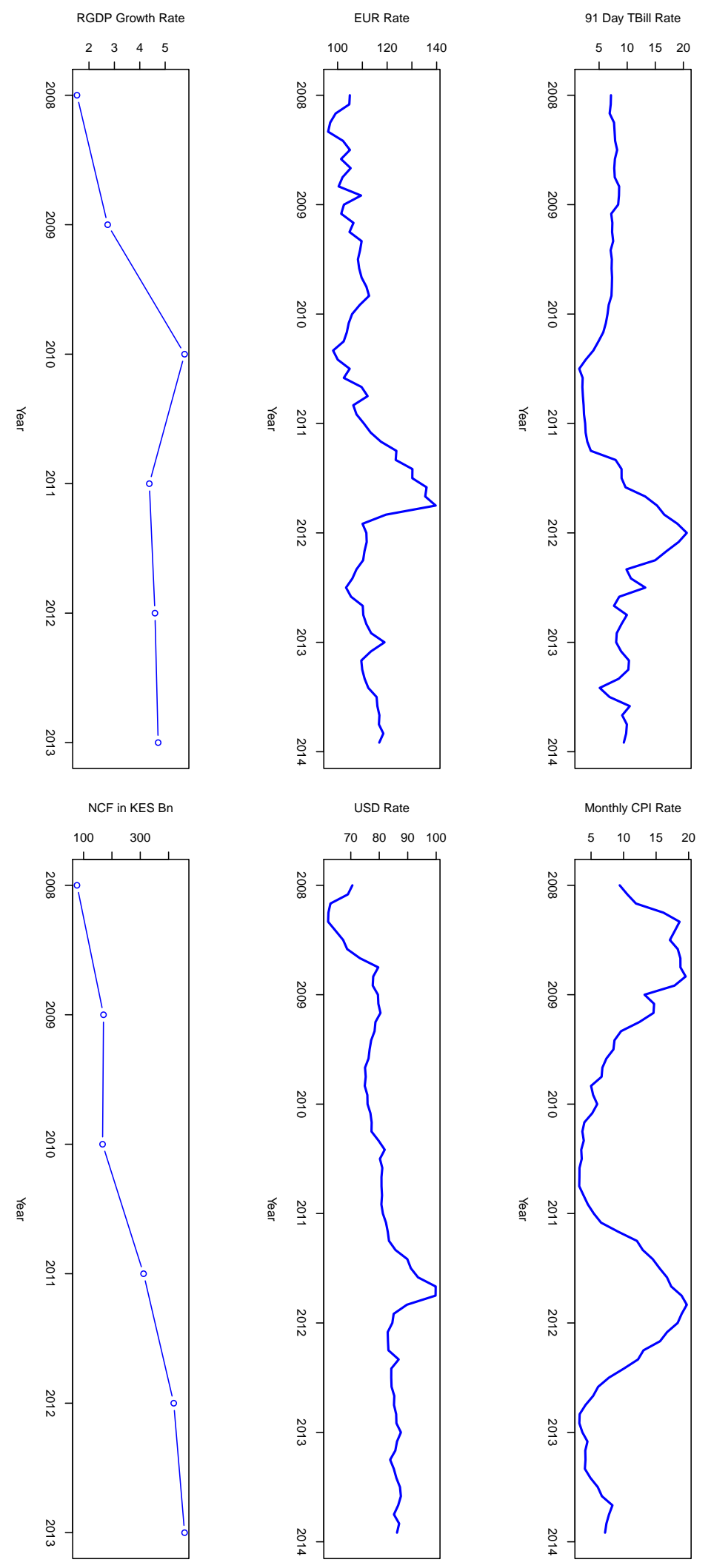
Figure 2: NPL Ratio depending on log-loan

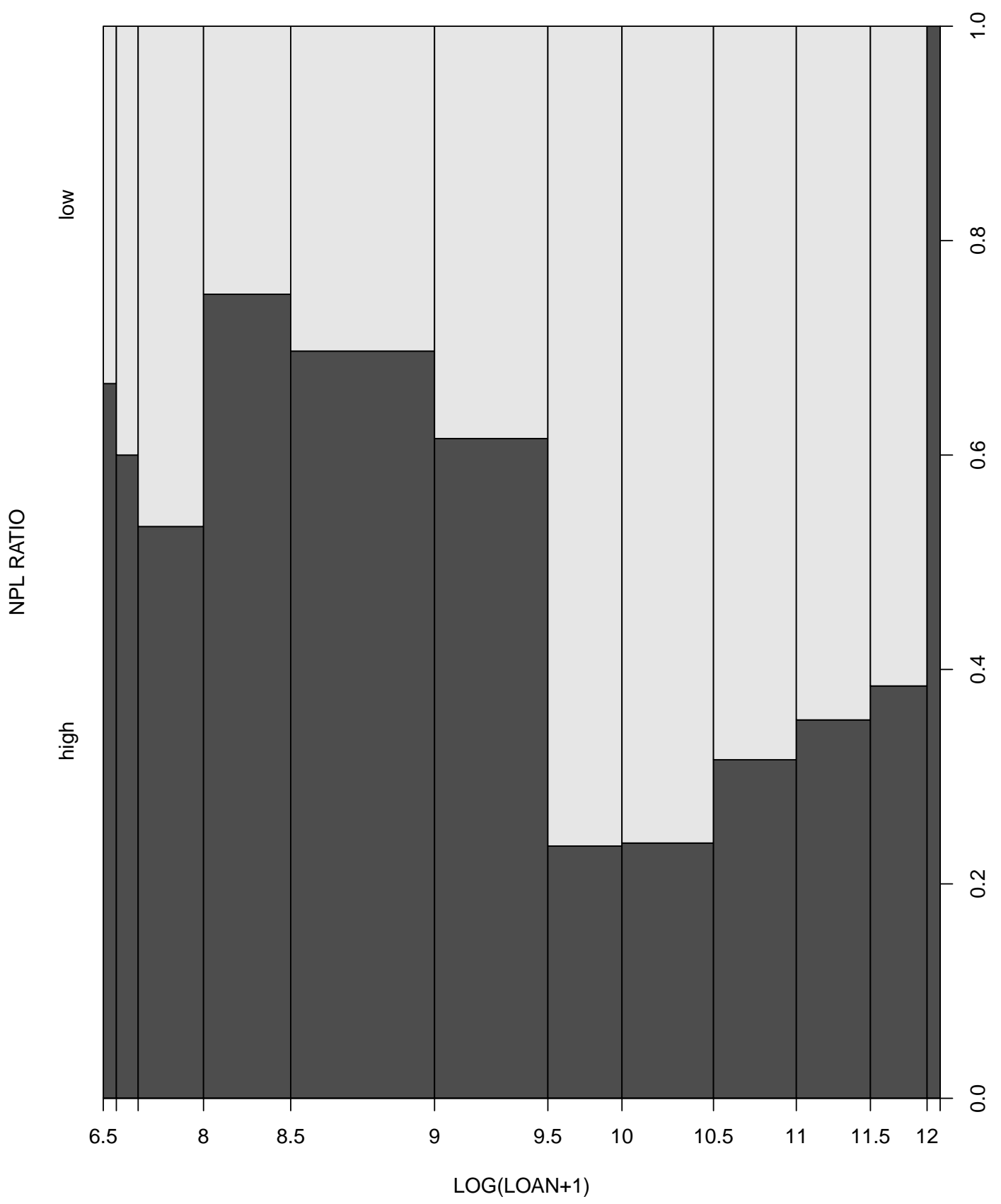


Figure 3: Distance from median ROE

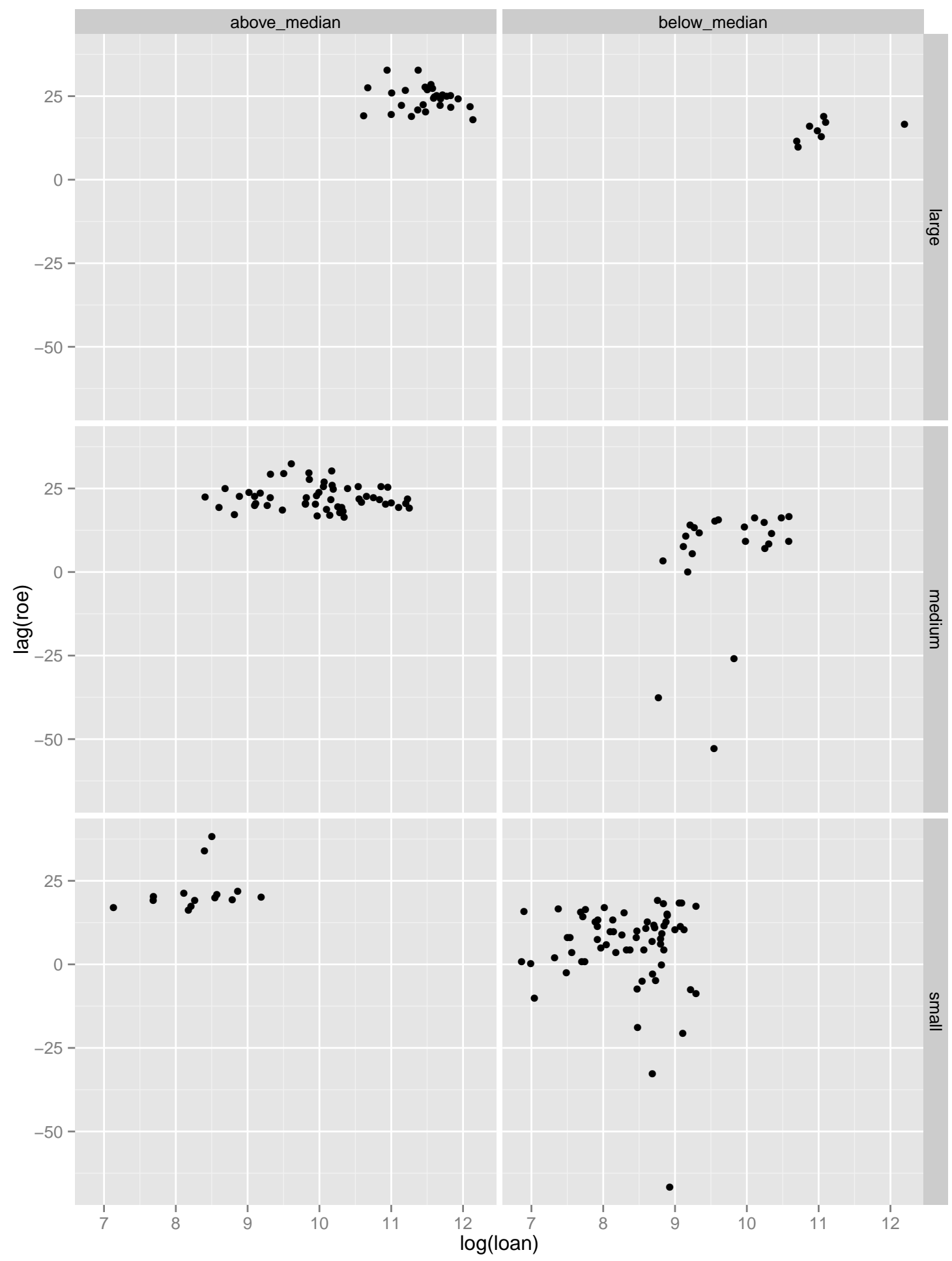


Table 1: Descriptive Statistics

\begin{tabular}{lrrrrr}
\hline Statistic & $N$ & Mean & St. Dev. & Min & Max \\
\hline Net Interest Margin, NIM & 192 & 9.63 & 3.98 & 0.23 & 25.89 \\
Lending Risk Exposure, LOG.LRE & 192 & 6.61 & 1.23 & 3.64 & 9.70 \\
Market Share, MSHARE & 192 & 3.13 & 3.59 & 0.10 & 15.31 \\
Degree of Diversification, DIVERSE & 192 & 34.15 & 12.41 & 6.90 & 94.98 \\
Loan to Assets Ratio, LTA & 192 & 52.61 & 11.24 & 21.01 & 75.66 \\
Loan Growth Rate, LOG.LOAN & 192 & 9.54 & 1.30 & 6.86 & 12.20 \\
Capital Adequacy Ratio, CAR & 192 & 22.85 & 9.36 & 8.87 & 64.78 \\
Real GDP Growth Rate, RGDPG & 192 & 3.95 & 1.41 & 1.53 & 5.76 \\
91-Day T-Bill Rate, INT & 192 & 8.06 & 2.64 & 3.17 & 11.01 \\
Inflation Rate, INFL & 192 & 9.81 & 4.58 & 3.80 & 16.58 \\
Net Capital Flows, NCF & 192 & 262.10 & 143.93 & 100.61 & 514.39 \\
US Dollar Exchange Rate, USD & 192 & 81.19 & 6.55 & 69.62 & 89.44 \\
Euro Exchange Rate, EUR & 192 & 110.86 & 6.44 & 104.03 & 123.29 \\
Degree of Concentration, CONC & 192 & 32.57 & 2.65 & 29.24 & 37.40 \\
Market Size, MSIZE & 192 & 34.33 & 3.86 & 29.13 & 39.42 \\
\hline
\end{tabular}

Table 2: Bank Sample Descriptive Statistics

\begin{tabular}{lrrrr}
\hline & All & Large & Medium & Small \\
\hline Total Assets in Mn & 55,188 & 169,665 & 48,943 & 9,108 \\
& $(65,878)$ & $(60,184)$ & $(27,670)$ & $(4,283)$ \\
Loans/Total Assets & $52.61 \%$ & $55.58 \%$ & $50.47 \%$ & $53.34 \%$ \\
& $(11.24)$ & $(6.78)$ & $(11.81)$ & $(11.99)$ \\
NPL/Loans & $7.62 \%$ & $4.78 \%$ & $4.33 \%$ & $12.12 \%$ \\
& $(8.68)$ & $(2.91)$ & $(4.81)$ & $(11.10)$ \\
Equity/Total Assets & $14.63 \%$ & $15.27 \%$ & $14.11 \%$ & $14.84 \%$ \\
& $(4.78)$ & $(4.23)$ & $(3.70)$ & $(5.84)$ \\
Return on Equity & $14.92 \%$ & $23.08 \%$ & $17.08 \%$ & $9.10 \%$ \\
& $(13.18)$ & $(5.36)$ & $(13.12)$ & $(13.23)$ \\
Return on Assets & $2.21 \%$ & $3.58 \%$ & $2.48 \%$ & $1.33 \%$ \\
& $(1.74)$ & $(1.28)$ & $(1.69)$ & $(1.48)$ \\
Net Interest Income/Total Income & $65.88 \%$ & $61.36 \%$ & $66.50 \%$ & $67.33 \%$ \\
& $(12.61)$ & $(6.47)$ & $(13.53)$ & $(13.43)$ \\
Non-Interest Revenue/Total Income & $34.15 \%$ & $38.64 \%$ & $33.50 \%$ & $32.73 \%$ \\
& $(12.41)$ & $(6.47)$ & $(13.53)$ & $(12.97)$ \\
Operating Expenses/Total Income & $65.55 \%$ & $59.26 \%$ & $58.20 \%$ & $75.57 \%$ \\
& $(31.23)$ & $(8.94)$ & $(38.43)$ & $(27.22)$ \\
Capital Adequacy Ratio & $22.85 \%$ & $21.45 \%$ & $22.03 \%$ & $24.28 \%$ \\
& $(9.36)$ & $(5.95)$ & $(9.06)$ & $(10.71)$ \\
\hline
\end{tabular}

Note: Means and Standard Deviations (in brackets) for the period 2008-13. 
Table 3: Correlation of Macroeconomic Variables

\begin{tabular}{lcccccc}
\hline & RGDPG & INT & INFL & NCF & USD & EUR \\
\hline RGDP & 1 & & & & & \\
INT & -0.16 & 1 & & & & \\
INFL & -0.72 & 0.53 & 1 & & & \\
NCF & 0.58 & 0.41 & -0.27 & 1 & & \\
USD & 0.74 & 0.47 & -0.27 & 0.82 & 1 & \\
EUR & 0.30 & 0.67 & 0.25 & 0.67 & 0.83 & 1 \\
\hline
\end{tabular}

Table 4: Panel Unit Root Tests Results

\begin{tabular}{|c|c|c|c|c|}
\hline Variable & ADF Test & PP Test & ERS Test & SP Test \\
\hline$\overline{\mathrm{RGDPG}}$ & $\begin{array}{c}11.86^{* * *} \\
(0.02)\end{array}$ & $\begin{array}{c}3.81^{* * *} \\
(0.30)\end{array}$ & $\begin{array}{c}-0.66^{* * *} \\
(0.09)\end{array}$ & $\begin{array}{c}3.86^{* * *} \\
(0.42)\end{array}$ \\
\hline INT & $\begin{array}{c}24.20^{* * *} \\
(1.16)\end{array}$ & $\begin{array}{c}8.09^{* * *} \\
(0.62)\end{array}$ & $\begin{array}{c}-2.93^{* * *} \\
(0.14)\end{array}$ & $\begin{array}{c}8.04^{* * *} \\
(0.84)\end{array}$ \\
\hline INFL & $\begin{array}{c}29.44^{* * *} \\
(0.77)\end{array}$ & $\begin{array}{c}14.34^{* * *} \\
(0.70)\end{array}$ & $\begin{array}{c}-0.10^{* * *} \\
(0.04)\end{array}$ & $\begin{array}{c}14.23^{* * *} \\
(1.12)\end{array}$ \\
\hline $\mathrm{NCF}$ & $\begin{array}{c}783.48^{* * *} \\
(44.15)\end{array}$ & $\begin{array}{c}274.21^{* * *} \\
(21.76)\end{array}$ & $\begin{array}{c}-0.92^{* * *} \\
(0.13)\end{array}$ & $\begin{array}{c}273.40^{* * *} \\
(37.29)\end{array}$ \\
\hline USD & $\begin{array}{c}242.40^{* * *} \\
(11.01)\end{array}$ & $\begin{array}{c}70.65^{* * *} \\
(5.85)\end{array}$ & $\begin{array}{c}-0.26^{* * *} \\
(0.07)\end{array}$ & $\begin{array}{c}70.87^{* * *} \\
(6.00)\end{array}$ \\
\hline EUR & $\begin{array}{c}332.50^{* * *} \\
(17.13)\end{array}$ & $\begin{array}{c}143.17^{* * *} \\
(7.73)\end{array}$ & $\begin{array}{c}-0.75^{* * *} \\
(0.12)\end{array}$ & $\begin{array}{c}143.20^{* * *} \\
(7.84)\end{array}$ \\
\hline $\mathrm{CONC}$ & $\begin{array}{c}97.04^{* * *} \\
(5.02)\end{array}$ & $\begin{array}{c}32.56^{* * *} \\
(2.37)\end{array}$ & $\begin{array}{c}-0.52^{* * *} \\
(0.10)\end{array}$ & $\begin{array}{c}32.48^{* * *} \\
(2.46)\end{array}$ \\
\hline MSIZE & $\begin{array}{c}102.80^{* * *} \\
(3.86)\end{array}$ & $\begin{array}{c}24.25^{* * *} \\
(2.41)\end{array}$ & $\begin{array}{c}-0.88^{* * *} \\
(0.12)\end{array}$ & $\begin{array}{c}24.30^{* * *} \\
(2.52)\end{array}$ \\
\hline NIM & $\begin{array}{c}3.80^{* * *} \\
(0.95)\end{array}$ & $\begin{array}{c}3.46^{* * *} \\
(0.58)\end{array}$ & $\begin{array}{c}-0.32^{* * *} \\
(0.07)\end{array}$ & $\begin{array}{c}5.15^{* * *} \\
(1.01)\end{array}$ \\
\hline LOG.LRE & $\begin{array}{c}1.85^{* * *} \\
(0.40)\end{array}$ & $\begin{array}{c}1.48^{* * *} \\
(0.31)\end{array}$ & $\begin{array}{c}-0.15^{* * *} \\
(0.04)\end{array}$ & $\begin{array}{c}1.94^{* * *} \\
(0.42)\end{array}$ \\
\hline MSHARE & $\begin{array}{c}0.49^{*} \\
(0.29)\end{array}$ & $\begin{array}{l}0.29^{* *} \\
(0.14)\end{array}$ & $\begin{array}{c}-0.04^{*} \\
(0.02)\end{array}$ & $\begin{array}{l}1.02^{* *} \\
(0.48)\end{array}$ \\
\hline DIVERSE & $\begin{array}{c}11.05^{* * *} \\
(2.98)\end{array}$ & $\begin{array}{c}15.01^{* * *} \\
(2.19)\end{array}$ & $\begin{array}{c}-0.25^{* * *} \\
(0.07)\end{array}$ & $\begin{array}{c}11.91^{* * *} \\
(2.86)\end{array}$ \\
\hline CTI & $\begin{array}{c}13.99^{* *} \\
(5.19)\end{array}$ & $\begin{array}{c}30.01^{* * * *} \\
(4.43)\end{array}$ & $\begin{array}{c}-0.24^{* * *} \\
(0.07)\end{array}$ & $\begin{array}{c}15.89^{* * * *} \\
(6.08)\end{array}$ \\
\hline LTA & $\begin{array}{c}11.90^{* * * *} \\
(2.92)\end{array}$ & $\begin{array}{c}15.76^{* * *} \\
(2.78)\end{array}$ & $\begin{array}{c}-0.28^{* * *} \\
(0.06)\end{array}$ & $\begin{array}{c}15.18^{* * *} \\
(3.05)\end{array}$ \\
\hline LOG.LOAN & $\begin{array}{c}2.23^{* * *} \\
(0.54)\end{array}$ & $\begin{array}{c}1.74^{* * *} \\
(0.42)\end{array}$ & $\begin{array}{c}-0.17^{* * *} \\
(0.05)\end{array}$ & $\begin{array}{c}2.51^{* * *} \\
(0.55)\end{array}$ \\
\hline CAR & $\begin{array}{c}11.17^{* * *} \\
(2.12)\end{array}$ & $\begin{array}{c}7.42^{* * *} \\
(1.31)\end{array}$ & $\begin{array}{c}-0.30^{* * *} \\
(0.06)\end{array}$ & $\begin{array}{c}9.00^{* * *} \\
(2.06)\end{array}$ \\
\hline ROE & $\begin{array}{l}5.98^{* *} \\
(2.32)\end{array}$ & $\begin{array}{c}6.11^{* * *} \\
(1.16)\end{array}$ & $\begin{array}{c}-0.29^{* * *} \\
(0.07)\end{array}$ & $\begin{array}{c}13.05^{* * *} \\
(2.94) \\
\end{array}$ \\
\hline
\end{tabular}

Note: ${ }^{* * *},{ }^{* * *}$ denote significance at $10 \%, 5 \%$ and $1 \%$ levels. 
Table 5: Baseline Two-Way Fixed Effects Regression for NIM

\begin{tabular}{lcccc}
\hline & All & Large & Medium & Small \\
\hline L1.NIM & $-0.153^{*}$ & 0.229 & 0.133 & $-0.490^{* * *}$ \\
& $(0.083)$ & $(0.279)$ & $(0.125)$ & $(0.138)$ \\
DIVERSE & $-0.128^{* * *}$ & -0.049 & $-0.103^{* * *}$ & $-0.086^{*}$ \\
& $(0.025)$ & $(0.061)$ & $(0.030)$ & $(0.046)$ \\
MSHARE & -0.206 & 0.400 & -0.232 & $-10.060^{* *}$ \\
& $(0.318)$ & $(0.258)$ & $(0.565)$ & $(4.327)$ \\
LTA & $-0.156^{* * *}$ & -0.048 & $-0.198^{* * *}$ & $-0.192^{* * *}$ \\
& $(0.039)$ & $(0.054)$ & $(0.056)$ & $(0.070)$ \\
\hline Observations & 160 & 30 & 66 & 64 \\
R $^{2}$ & 0.267 & 0.245 & 0.395 & 0.393 \\
Adjusted R & 0.201 & 0.131 & 0.264 & 0.264 \\
F Statistic & $10.954^{* * *}$ & 1.298 & $7.196^{* * *}$ & $6.970^{* * *}$ \\
& $(\mathrm{df}=4 ; 120)$ & $(\mathrm{df}=4 ; 16)$ & $(\mathrm{df}=4 ; 44)$ & $(\mathrm{df}=4 ; 43)$ \\
\hline
\end{tabular}

Note: ${ }^{* * *},{ }^{* * *}$ denote significance at $10 \%, 5 \%$ and $1 \%$ levels. Standard errors in brackets.

Table 6: Baseline Two-Way Fixed Effects Regression for LRE

\begin{tabular}{lcccc}
\hline & All & Large & Medium & Small \\
\hline L1.LOG.LRE & $0.351^{* * *}$ & 0.111 & $0.244^{*}$ & $0.388^{* *}$ \\
& $(0.083)$ & $(0.202)$ & $(0.130)$ & $(0.144)$ \\
L1.CAR & -0.001 & $0.033^{* *}$ & -0.009 & -0.011 \\
& $(0.007)$ & $(0.015)$ & $(0.014)$ & $(0.012)$ \\
MSHARE & 0.004 & -0.110 & 0.116 & 0.911 \\
& $(0.066)$ & $(0.098)$ & $(0.141)$ & $(0.828)$ \\
L1.LOG.LOAN & $0.848^{* * *}$ & $2.061^{* * *}$ & $0.878^{* *}$ & 0.265 \\
& $(0.226)$ & $(0.613)$ & $(0.329)$ & $(0.434)$ \\
\hline Observations & 160 & 30 & 66 & 64 \\
R $^{2}$ & 0.361 & 0.602 & 0.378 & 0.370 \\
Adjusted R & 0.270 & 0.321 & 0.252 & 0.249 \\
F Statistic & $16.923^{* * *}$ & $6.043^{* * *}$ & $6.693^{* * *}$ & $6.325^{* * *}$ \\
& $(\mathrm{df}=4 ; 120)$ & $(\mathrm{df}=4 ; 16)$ & $(\mathrm{df}=4 ; 44)$ & $(\mathrm{df}=4 ; 43)$ \\
\hline
\end{tabular}

Note: ${ }^{* * *},{ }^{* *}$ denote significance at $10 \%, 5 \%$ and $1 \%$ levels. Standard errors in brackets. 
Table 7: GMM Regression Results for Net Interest Margin

\begin{tabular}{|c|c|c|c|c|c|c|}
\hline & (1) & $(2)$ & $(3)$ & $(4)$ & $(5)$ & (6) \\
\hline \multirow[t]{2}{*}{ L1.NIM } & -0.149 & -0.149 & -0.128 & -0.067 & -0.097 & -0.095 \\
\hline & $(0.151)$ & $(0.149)$ & $(0.152)$ & $(0.121)$ & $(0.147)$ & $(0.146)$ \\
\hline \multirow[t]{2}{*}{ DIVERSE } & $-0.145^{* * *}$ & $-0.144^{* * *}$ & $-0.147^{* * *}$ & $-0.142^{* * *}$ & $-0.148^{* * *}$ & $-0.148^{* * *}$ \\
\hline & $(0.028)$ & $(0.028)$ & $(0.028)$ & $(0.027)$ & $(0.028)$ & $(0.028)$ \\
\hline \multirow[t]{2}{*}{ L1.DIVERSE } & 0.014 & 0.013 & 0.023 & 0.028 & 0.030 & 0.031 \\
\hline & $(0.025)$ & $(0.025)$ & $(0.024)$ & $(0.025)$ & $(0.024)$ & $(0.024)$ \\
\hline \multirow[t]{2}{*}{ MSHARE } & -0.389 & -0.391 & -0.369 & -0.343 & -0.348 & -0.346 \\
\hline & $(0.385)$ & $(0.384)$ & $(0.385)$ & $(0.360)$ & $(0.381)$ & $(0.381)$ \\
\hline \multirow[t]{2}{*}{ LTA } & $-0.168^{* * *}$ & $-0.170^{* * *}$ & $-0.158^{* * *}$ & $-0.166^{* * *}$ & $-0.153^{* * *}$ & $-0.153^{* * *}$ \\
\hline & $(0.045)$ & $(0.045)$ & $(0.044)$ & $(0.044)$ & $(0.044)$ & $(0.044)$ \\
\hline \multirow[t]{2}{*}{ L1.LTA } & $-0.072^{*}$ & $-0.072^{*}$ & $-0.076^{*}$ & $-0.081^{*}$ & $-0.080^{*}$ & $-0.080^{*}$ \\
\hline & $(0.043)$ & $(0.042)$ & $(0.044)$ & $(0.043)$ & $(0.045)$ & $(0.045)$ \\
\hline \multirow[t]{2}{*}{ CONC } & 0.953 & $1.062^{*}$ & $1.207^{* *}$ & -0.325 & $1.420^{* *}$ & $1.121^{*}$ \\
\hline & $(0.636)$ & $(0.579)$ & $(0.578)$ & $(1.213)$ & $(0.598)$ & $(0.590)$ \\
\hline \multirow[t]{2}{*}{ MSIZE } & 0.329 & 0.394 & $0.456^{*}$ & 0.077 & $0.682^{* *}$ & $0.452^{*}$ \\
\hline & $(0.305)$ & $(0.267)$ & $(0.266)$ & $(0.364)$ & $(0.293)$ & $(0.271)$ \\
\hline \multirow[t]{2}{*}{ RGDPG } & 0.073 & & & & & \\
\hline & $(0.140)$ & & & & & \\
\hline \multirow[t]{2}{*}{ INT } & & -0.009 & & & & \\
\hline & & $(0.041)$ & & & & \\
\hline \multirow[t]{2}{*}{ INFL } & & & $-0.049^{*}$ & & & \\
\hline & & & $(0.026)$ & & & \\
\hline \multirow[t]{2}{*}{$\mathrm{NCF}$} & & & & -0.009 & & \\
\hline & & & & $(0.007)$ & & \\
\hline \multirow[t]{2}{*}{ USD } & & & & & $-0.130^{* *}$ & \\
\hline & & & & & $(0.065)$ & \\
\hline \multirow[t]{2}{*}{ EUR } & & & & & & $-0.049^{* *}$ \\
\hline & & & & & & $(0.025)$ \\
\hline Num. obs. & 192 & 192 & 192 & 192 & 192 & 192 \\
\hline Num. obs. used & 128 & 128 & 128 & 128 & 128 & 128 \\
\hline Sargan Test: p-value & 0.936 & 0.933 & 0.946 & 0.922 & 0.945 & 0.944 \\
\hline AR (1) Test: p-value & 0.005 & 0.005 & 0.007 & 0.008 & 0.008 & 0.008 \\
\hline AR (2) Test: p-value & 0.237 & 0.249 & 0.190 & 0.217 & 0.181 & 0.182 \\
\hline Wald Test: p-value & 0.000 & 0.000 & 0.000 & 0.000 & 0.000 & 0.000 \\
\hline
\end{tabular}

Note: ${ }^{* * *},{ }^{* * *}$ denote significance at $10 \%, 5 \%$ and $1 \%$ levels. Standard errors in brackets. 
Table 8: GMM Regression Results for Lending Risk Exposure

\begin{tabular}{|c|c|c|c|c|c|c|}
\hline & (1) & $(2)$ & (3) & (4) & (5) & (6) \\
\hline \multirow[t]{2}{*}{ L1.LOG.LRE } & $0.506^{* *}$ & $0.501^{* *}$ & $0.641^{* * *}$ & $0.651^{* * *}$ & $0.651^{* * *}$ & $0.680^{* * *}$ \\
\hline & $(0.202)$ & $(0.202)$ & $(0.195)$ & $(0.210)$ & $(0.210)$ & $(0.201)$ \\
\hline \multirow[t]{2}{*}{ CAR } & 0.001 & 0.001 & 0.001 & 0.003 & 0.003 & 0.002 \\
\hline & $(0.006)$ & $(0.006)$ & $(0.007)$ & $(0.007)$ & $(0.007)$ & $(0.007)$ \\
\hline \multirow[t]{2}{*}{ MSHARE } & -0.029 & -0.027 & -0.093 & -0.111 & -0.110 & -0.117 \\
\hline & $(0.070)$ & $(0.070)$ & $(0.075)$ & $(0.081)$ & $(0.081)$ & $(0.079)$ \\
\hline \multirow[t]{2}{*}{ LOG.LOAN } & $0.821^{* *}$ & $0.813^{* *}$ & $1.010^{* *}$ & $0.935^{* *}$ & $0.933^{* *}$ & $1.019^{* *}$ \\
\hline & $(0.365)$ & $(0.361)$ & $(0.450)$ & $(0.427)$ & $(0.427)$ & $(0.455)$ \\
\hline \multirow[t]{2}{*}{ L1.LOG.LOAN } & -0.067 & -0.064 & -0.063 & 0.101 & 0.102 & 0.020 \\
\hline & $(0.316)$ & $(0.315)$ & $(0.333)$ & $(0.309)$ & $(0.311)$ & $(0.326)$ \\
\hline \multirow[t]{2}{*}{ L1.CONC } & 0.020 & $0.061^{*}$ & 0.022 & $0.131^{* * *}$ & $0.205^{* * *}$ & $0.128^{* * *}$ \\
\hline & $(0.036)$ & $(0.035)$ & $(0.036)$ & $(0.048)$ & $(0.079)$ & $(0.044)$ \\
\hline \multirow[t]{2}{*}{ L1.MSIZE } & 0.019 & -0.011 & -0.031 & $-0.058^{*}$ & -0.007 & -0.003 \\
\hline & $(0.017)$ & $(0.017)$ & $(0.019)$ & $(0.035)$ & $(0.018)$ & $(0.017)$ \\
\hline \multirow[t]{2}{*}{ L1.RGDPG } & $-0.116^{* * *}$ & & & & & \\
\hline & $(0.032)$ & & & & & \\
\hline \multirow[t]{2}{*}{ L1.INT } & & $0.043^{* * *}$ & & & & \\
\hline & & $(0.012)$ & & & & \\
\hline \multirow[t]{2}{*}{ L1.INFL } & & & $0.032^{* * *}$ & & & \\
\hline & & & $(0.009)$ & & & \\
\hline L1.NCF & & & & $0.003^{* * 4}$ & & \\
\hline \multirow[t]{2}{*}{ L1.USD } & & & & & $0.045^{* *}$ & \\
\hline & & & & & $(0.022)$ & \\
\hline \multirow[t]{2}{*}{ L1.EUR } & & & & & & $0.020^{* * *}$ \\
\hline & & & & & & $(0.007)$ \\
\hline Num. obs. & 192 & 192 & 192 & 192 & 192 & 192 \\
\hline Num. obs. used & 128 & 128 & 128 & 128 & 128 & 128 \\
\hline Sargan Test: p-value & 0.999 & 0.999 & 0.997 & 0.999 & 0.998 & 0.997 \\
\hline AR (1) Test: p-value & 0.057 & 0.060 & 0.021 & 0.025 & 0.025 & 0.020 \\
\hline AR (2) Test: p-value & 0.804 & 0.811 & 0.616 & 0.716 & 0.715 & 0.693 \\
\hline Wald Test: p-value & 0.000 & 0.000 & 0.000 & 0.000 & 0.000 & 0.000 \\
\hline
\end{tabular}

Note: ${ }^{*},{ }^{* * * *}$ denote significance at $10 \%, 5 \%$ and $1 \%$ levels. Standard errors in brackets. 
Table 9: Coefficient Estimates for the PVAR Model

\begin{tabular}{lcccccc}
\hline & $U S D_{t}$ & $I N T_{t}$ & $R G D P G_{t}$ & $L O G . L R E_{t}$ & $L O G . L O A N_{t}$ & $C A R_{t}$ \\
\hline$U S D_{t-1}$ & $1.150^{* * *}$ & $0.020^{* * *}$ & $0.075^{* * *}$ & 0.002 & $0.007^{* * *}$ & $0.216^{* *}$ \\
& $(0.024)$ & $(0.005)$ & $(0.002)$ & $(0.005)$ & $(0.002)$ & $(0.088)$ \\
& $-1.657^{* * *}$ & $0.114^{* * *}$ & $-0.075^{* * *}$ & $0.037^{* *}$ & $-0.020^{* * *}$ & -0.248 \\
& $(0.027)$ & $(0.007)$ & $(0.003)$ & $(0.015)$ & $(0.006)$ & $(0.170)$ \\
$R G D P T_{t-1}$ & $-1.361^{* * *}$ & $1.347^{* * *}$ & $-0.041^{* * *}$ & -0.012 & -0.013 & $-1.306^{* * *}$ \\
& $(0.073)$ & $(0.016)$ & $(0.006)$ & $(0.030)$ & $(0.011)$ & $(0.453)$ \\
LOG.LRE & 0.320 & $-0.161^{* *}$ & 0.039 & $0.863^{* * *}$ & -0.002 & $-0.921^{*}$ \\
& $(0.213)$ & $(0.070)$ & $(0.033)$ & $(0.038)$ & $(0.019)$ & $(0.493)$ \\
LOG.LOAN $N_{t-1}$ & $0.598^{* * *}$ & $0.175^{* * *}$ & $-0.107^{* * *}$ & $0.075^{* *}$ & $0.990^{* * *}$ & 0.108 \\
& $(0.126)$ & $(0.057)$ & $(0.025)$ & $(0.035)$ & $(0.014)$ & $(0.431)$ \\
CAR & $0.080^{* * *}$ & -0.006 & -0.003 & -0.005 & -0.001 & $0.768^{* * *}$ \\
& $(0.017)$ & $(0.006)$ & $(0.002)$ & $(0.004)$ & $(0.002)$ & $(0.055)$ \\
\hline
\end{tabular}

Note: ${ }^{* * *},{ }^{* * *}$ denote significance at $10 \%, 5 \%$ and $1 \%$ levels. Standard errors in brackets. 